\title{
Factors of Human Resource Management Practices Affecting Organizational Performance
}

\author{
Saunah Zainon ${ }^{1 *}$, Rina Fadhilah Ismail ${ }^{2}$, Raja Adzrin Raja Ahmad ${ }^{3}$, Roslina Mohamad \\ Shafi $^{4}$, Faridah Najuna Misman ${ }^{5}$, Sofwah Md Nawi ${ }^{6}$, Juliana Mohamed Abdul Kadir ${ }^{7}$
}

\author{
1,3 Faculty of Accountancy, UiTM Cawangan Johor, Segamat Campus, Johor, Malaysia \\ ${ }^{2}$ Faculty of Accountancy, UiTM Cawangan Selangor, Puncak Alam Campus, Malaysia \\ 4,5,7 Faculty of Business Management, UiTM Cawangan Johor, Segamat Campus, Malaysia \\ 6 Academy of Language Studies, UiTM Cawangan Johor, Segamat Campus, Malaysia
}

\section{Keywords: \\ Human Resource \\ Management Practices, \\ Organizational Performance, \\ Training}

\section{Received}

25 September 2020

Received in revised form

01 October 2020

Accepted

28 October 2020

*Correspondence:

sauna509@uitm.edu.my

\begin{abstract}
The purpose of this study is to examine factors of human resource management practices affecting organizational performance. This study employed descriptive method in gathering, analyzing, interpreting, and presenting the information. The descriptive research design helped in identifying the strength of the relationship between factors of human resource management practices affecting organizational performance. Questionnaires were distributed to employees of Jakel Trading Company in Johor, Malaysia and of the total obtained, 139 responses were usable and analyzed. Inferential statistics were also performed for data analysis and presentation purposes. Correlations and frequencies were among the statistical measures used in this study. Based on the findings, all three hypotheses formed at the beginning of the study were supported. The results of multiple regression showed that staff training, performance appraisal and rewards, as well as recognition are all significant factors of human resource management practices affecting organizational performance. It was also found that staff training and recognition do affect the organizational performance as a whole. This study provides input to employers on how to reward and motivate their staff for better performance.
\end{abstract}

@CIKD Publishing

Change is crucial for any organizations because it involves a long-term operation in adapting to market condition. Dobrovic and Timkova (2017) state that for a successful long-term operation, an important prerequisite organization is the ability to predict events and to adapt to market conditions. 
The importance to react to current market conditions and market environment is also emphasized by Civelek, Ključnikov, Dobrovič and Hudáková (2016). Change is inevitable to all business and organization. Halkos (2012) states that organizational changes deal with transactional change and transformational change. Rather than reacting to change, it is crucial for every organization to manage all employees in adapting change. Employees plays important role in the organization in achieving organization's goal, mission and vision. Thus, they need to face changes in reaching achieving target. Moreover, change becomes more rapid these days to complexity of political issues, rapid changes in technology and also fluctuating economy. Thus, organizations need to identify solutions driving towards a successful change in organization.

Adapting change requires organization to commit in a continuous process to ensure understanding about the changes. Halkos (2012) states that it is the basic parameter to their development as innovation and change requires timely and continuous adaptation of a company. The change process is the means to transform an organization which involves several stages including performing organizational audit, planning, formulating change strategy, communicating, persuading others and consolidating the change. Therefore, top management, middle level management and lower level management in an organization need to manage properly in adapting changes so that the change can be conducted successfully.

The performance of an organization comes from a successful change management to survive and succeed in adapting with current environment. The concept of change is that it needs to continuously evolve to make sure it is aligned with the environmental factors (Al-Haddad and Kotnour, 2015). In the Malaysian context, Jakel Trading Company is one of the organizations that was involved in change management practices. Being the largest textile company in the country, Jakel Trading Company started as a small textile business and began to grow rapidly after opening their first branch in Johor in 1985. Currently, Jakel Trading Company has over 5,000 employees. The increase in demands and needs by customer prompted inevitable changes.

In this case, the changes involved the structure of the company due to the increase in number of employees. At the same time, the position of its members as well as their knowledge and skills were also affected. Besides that, the company's growth and development create a higher consumption in advanced technology as these technologies are also used in managing from one branch to another. In the process of change, the company conducted staff training, measured employees' performance through performance appraisal as well as adjusted their rewards and recognition. Given the changes that take place, this research aims to investigate these three factors and how they affect change management towards organizational performance.

\section{Problem Statement}

Organizations are involved with various types of changes such as market conditions, technological advancement, demographics profiling, economical condition, customer's loyalty and quality. When managing these changes, organizations often faced many challenges for its change management implementation. These challenges include inadequate planning, absence of training programs or management mistakes as well as lack of rewards and recognition for employees. Similar to other organizations, Jakel Trading Company Segamat also faced the issue of change management in mobilizing its employees for better performance.

Currently, the organizational performance of Jakel Trading Company is measured by the sales profit of the organization as well as the sales made from its employees. This is due to certain reasons such as the Internet of Things in the era of industrial revolution that affects the company planning 
and strategy in increasing the sales of Jakel Trading Company Segamat. Online transactions of buying and selling do affect the physical and traditional way of trading by Jakel. Thus, increasing the employees' efforts through training and development, reward and recognition and performance appraisal may influence performances of the organization.

Many studies had shown how change management processes have failed. Hughes (2011) posits that a 70 percent failure rate is frequently attributed to organizational-change initiatives. Even worse, according to Decker et al. (2012), failure rates may be as high as 93 percent. A failure of change management causes the organizational culture to change and staff morale decline rapidly which further leads to a poor business performance. One of the main commonly cited reasons for failures was employee resistance to change (Merkova, Rajnoha, \& Dobrovic, 2016).

Some authors focus on other factors of resistance to change such as planning of change process, time needed to change or monitoring upon change (Dobrovic \& Timkova, 2017). However, Jakel Trading Company Segamat is having issues in monitoring employees' performances. Thus, it is one of the major concerns that can affect the organizational performance. Besides that, in Jakel Trading Company, negative conflicts between employees and managers arise because of poor employee performances. Those conflicts exist from dissatisfaction of individual employees as they do not understand their scope of work that they need to perform, and they also misunderstood what is expected from them. Hence, this will lead towards poor performance of organizational performance. Moreover, managing new employees is one of the issues plaguing Jakel Trading Company Segamat. Commonly, they have trouble in making sales to generate profits for the organization. As such, their poor performance will inevitably cause a reduction in the organizational performance.

Change management failure renders them unable to compete in the market which leads towards poor organizational performances. Sanyal and Hisam (2018) stated that organizations which do not provide training to their employees causes them fail to compete in the market. Therefore, it causes the organization's budget to overrun as the changes occurred beyond what is expected. Despite failures to change, it is important to recognise the need for change as well as the implementation of change strategies. This includes the success factors of internal and external environment to change.

There are many studies conducted on factors affecting change management which could lead to organizational performance. Appelbaum et al. (2017) postulates that if change is not well-managed, it may cause significant disruption to the business and consequently impact organizational performance. The implication of organization failures leads to a poor organizational performance. In turn, organizational performance can be affected when there is an increase in staff turnover. A poorly trained employees leads to unsafe work environment, unsatisfied employees and reduced productivity. This is because the employees are not ready to adapt to changes as well as achieving organization's goals and objectives.

There are very few empirical studies linking the factors affecting change management to organizational or improved performance. McLagan (2009) attempted addressing change management process but fail to link it with the organizational performance. This left some gaps that inspired the researcher to study factors affecting change management which consequently leads to organizational performance. Without fairness of the performance appraisal system, rewards and motivations, it creates negative impact and frustration (Iqbal, 2014). 


\section{Research Objectives}

The objectives of the study are:

i. To determine whether there is a significant relationship between staff training and organizational performance.

ii. To determine whether there is a significant relationship between performance appraisal and organizational performance.

To identify whether there is a significant relationship between rewards and recognition and organizational performance.

\section{Review of the Literature}

Change is a common phenomenon in business. It is a matter on keeping up with current condition, situation and environment. Different authors describe the concept of change with different understanding. According to Pakdel (2016), change happens when something moves from one level to another and in organizational context, the state of activities taking place in an organization become different from the current ones. Rein, Jan and Wilfred (2016) defined that change comes in many different forms and levels of complexity while Bejinariu, Jitarel, Sarca and Mocan (2017) posits that organizational change involves changes of organizations' mission, vision or processes which brings impacts to individual and organizational level.

The need for change of an organization is actually the need of the company itself and it comes in the form of internal and external causes. External causes could come in the form of economy, politic, markets conditions, demands and wants, or competition whereas factors such as performance appraisal, training, reward and recognition is categorized into internal causes. Whatever the direction the reason for change may come from the inside or the outside environment, the aim is to transport improvement and progress in a certain area (Dobrovic \& Timkova, 2017). Thus, Dobrovic and Timkova (2018) describe change management as a systematic approach that helps organizations and individuals cope with change and its effects. Managing change management is crucial in dealing with changes as it helps organizations adapt with situation and environment. It is also crucial as it leads to organizational performance.

\section{Organizational Performance}

The concept of organizational performance is very common but it comes with many definitions (Gavrea, Ilieş, \& Stegerean, 2011). According to Cho and Dansereau (2010), organizational performance indicates the performance of a company by comparing with its goals and objectives. Basically, organizational performance is to achieve organization's objectives, goals and missions as well as its strategic aims. Organizational performance is affected by change management. According to Chandrasekar (2011), poor workplace environment causes dissatisfaction among individual employee which leads to a reduction in his or her productivity, thereby leading to a worsened organizational performance.

Therefore, organizational performance is an important criterion in evaluating organizations. In the same vein, the employees' performance towards an organization is crucial in contributing towards organizational performance. Iqbal, Ahmad, Haider, Batool and Ain (2014) states that organizations need high performance employees so that organization can meet their goals and achieve the competitive advantage. 


\section{Relationship between Staff Training and Organizational Performance}

Training is the orderly process of shifting the behaviour as well as attitudes of the workforce in line with pursuing organizational objectives which serves as a critical subject of human capital management and is also the fastest rising part of workers' performance (Adeyi, Apansile, Okere, \& Okafor, 2018). According to Ahmad and Din (2009), training and development increase performance of employee where training and development is an activity that is significant to improve the performance of health sector of the organization.

Abbas (2014) highlighted training as an important aspect to employees for the company development because some employees lack the knowledge, skills and competencies and thus failed to perform tasks on a timely basis. Therefore, training aids employees to earn knowledge about their job in a greater approach (Deming, 1982) as such activities are conducted to adjust the workers to adopt the policies, rules and methods accompanying the new case and to make them react in accordance with the procedures (Ikinci, 2014).

Change occurs whenever there is a gap in organizational performance (Rosenberg \& Mosca, 2016). When change is implemented, training allows supervisors, managers and directors to receive feedback and evaluation of performance. Training and development give benefits to employees such as better position and better career life as they improve employee performance thus, skilled employees will lead towards organizations efficiency and performance (Shafiq \& Hamza, 2017).

Tabassi, Ramni and Bakar (2011) identified that training develops people, improves performance and morale as well as increases effectiveness and productivity of the organization. This is supported by Sanyal and Hisam (2018), who found that training is important to ensure employees' performance by retaining motivation, satisfaction and competencies. Ghafoor, Furqan and Aslam (2011) also highlight that training brings more advantages rather than disadvantages as training gives positive impacts and it improves the organizations performance. Therefore, organizations should strive to provide training and development because it is important in improving organizational performance (Butali \& Njoroge, 2017) so as to ensure that they can successfully compete in the market (Sanyal \& Hisam, 2018).

\section{Relationship between Performance Appraisal and Organizational Performance}

Performance appraisal is an on-going process which measures employees' performance individually in achieving organizational goals. Organizations use performance appraisal to make administrative decision about employees especially related to promotion, current performance, administrating salary, the need for training as well as the developmental plan for employees (Siaguru, 2011). Performance appraisal benefits both parties in a number of ways. For example, employees identify what is expected from them and they also have a better understanding on their faults and strengths so they can adjust their behaviour (Mwema \& Gachunga, 2014). Moreover, appraisals help in providing feedback to workers about individual behaviour and it also allows employees to provide input to their managers (ibid).

Performance appraisal also increases employees' motivation to work as reported by Wan, Kok and Hong (2002). Similarly, Siaguru (2011) found that an effective performance appraisal motivates managers and employees to perform their jobs so as the allocated benefit from the reward. Since the appraisal system impacts employees' perception on fairness and justice, in turn, it affects their attitudes and behaviour which influences the performance of the organization (Ahmed, Ramzan, Mohammad, \& Islam, 2011). As reported by Zaleska and de Menezes (2007), employees 
show high level of commitment for their organizations through growing opportunities provided by the organization.

\section{Relationship between Reward and Recognition with Organizational Performance}

Human capital helps an organization to build a solid foundation for profitability and success (Sehgal, 2012). This is because, each and every employee plays an important role to help the organization achieve its targeted goals. As such, keeping employees satisfied in the organization is essential so that they can perform. According to Goulet and Singh (2002), it was found that employees who feel valued understand their role in achieving the organization's goals and have career commitment towards their job.

A reward and compensation system makes employees become more motivated to perform when there is a strong link between their performance and the reward they receive (Fey \& Bjorkman, 2001). Since rewards and recognitions are a return from employees work and performance, Aktar (2012) states that prioritizing both will increase employees' performance. Goel (2008) highlights that performance related pay is an effective motivator and it conveys a clear message on expectation of high-level performance and will be rewarded. Deeprose (1994) argued that an effective recognition enhances motivation of employees as well as their productivity and it results in improved performance of organizations. In the same vein, Yang and Kim (2013) explained that salary, benefits and remuneration packages offered by the organization can increase the job satisfaction of employees.

Therefore, Markos and Sridevi (2010) stated that an important management strategy to improve employees' performance is to incentivise employees either financially or non-financially. They also advocate that if employees' working efforts are recognized and being paid more, they tend to be more engaged in their work. Onyango (2012) concludes that if rewards of employees are aligned with the strategic objectives of the organization, there is an equivalent increase in performance.

\section{Research Framework and Hypotheses}

The main objective of this study is to examine factors affecting change management and determining the change management towards organizational performance. The research framework is depicted in Figure 1.

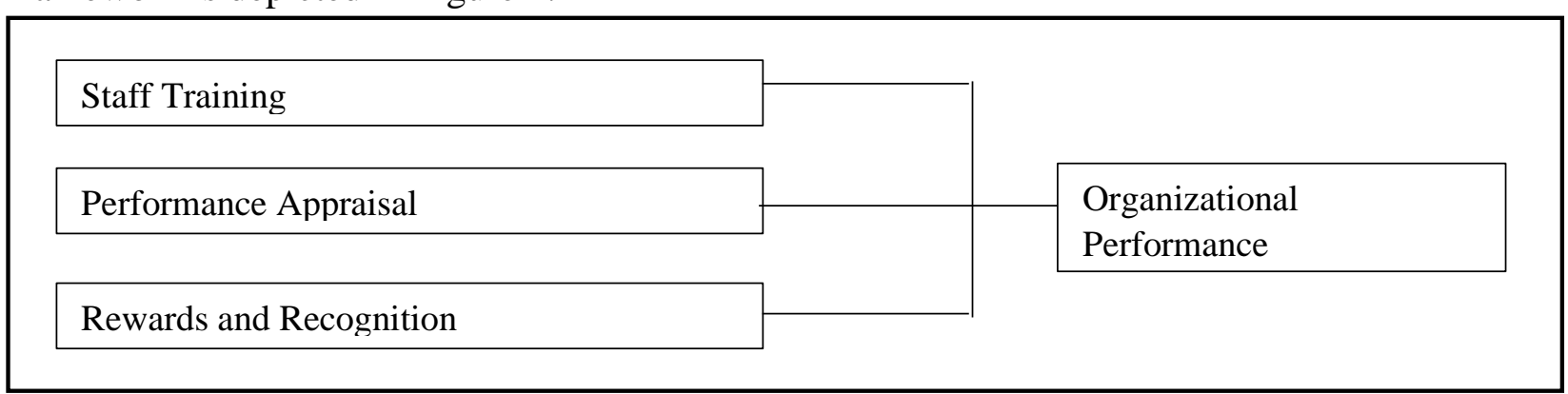

Figure 1. Research Framework

Consistent with the discussion and the explanation of the literature reviews, the following hypotheses have been developed to examine the relationship between the variables:

$\mathbf{H}_{0}$ : There is no relationship between staff training and the organizational performance.

$\mathbf{H}_{1}$ : There is a relationship between staff training and the organizational performance.

Ho: There no is relationship between performance appraisal and the organizational performance. 
$\mathbf{H}_{2}$ : There is a relationship between performance appraisal and the organizational performance.

$\mathbf{H}_{0}$ : There is no relationship between rewards and recognition and the organizational performance. H3: There is a relationship between rewards and recognition and the organizational performance.

\section{Method}

This research was conducted at Jakel Trading Company Segamat in Johor, Malaysia. The number of populations is 258, comprising all employees of Jakel Trading Company from the Segamat Branch. These include the top-level management, middle level management and lower level management personnel. A simple stratified random sampling was used and the targeted sample in this study were 155 employees of Jakel Trading Company Segamat.

The instrument used by the researcher to collect data is a questionnaire containing three sections that were prepared both in English and Bahasa Melayu. Items in the questionnaire were adopted from Basil and Helen (2013), Engetou (2017), Wachiuri (2017), Nassazi (2013), Asfaw, Asgaw and Bayissa (2015), Yasmeen, Farooq and Asgha (2013) and Iqbal et al. (2014). To test both consistency and stability of the data, a reliability analysis was conducted. Data from the questionnaire were tabulated and analysed using descriptive analysis and inferential statistics.

\section{Findings}

\section{Demographic Profile of the Respondents}

A total of 155 questionnaires distributed. However, only 139 questionnaires were returned and usable. This section explains the details of respondent about their gender, age, education level and position at Jakel Trading Company Segamat. As shown in Table 1, most of the respondents were female $(63.3 \%)$ and the remaining $36.7 \%$ were male. Their ages ranged from 18 to 46 years old and above with a large majority $(61.2 \%)$ of the respondents were between the age of 18 to 24 years old. Almost half of the respondents $(49.6 \%)$ possessed the entry level qualification namely the Malaysian Certificate of Education (MCE) while the remaining either possessed diploma (33.8\%), degree $(14.4 \%)$ or post-graduate education $(2.1 \%)$. The respondents represented various different positions in the company. The largest percentage of the respondents $(44.6 \%)$ were salespersons, followed by clerks $(34.5 \%)$. The remaining were helpers, technical staffs or hold other positions.

Table 1

Gender of Respondents $(n=139)$

\begin{tabular}{|c|c|c|c|}
\hline & & Frequency & Percentage $(\%)$ \\
\hline \multirow[t]{3}{*}{ Gender } & Female & 88 & 63.3 \\
\hline & Male & 51 & 36.7 \\
\hline & Total & 139 & 100 \\
\hline \multirow[t]{5}{*}{ Age (Years) } & $18-24$ & Age (Years) & Age (Years) \\
\hline & $25-35$ & Age (Years) & Age (Years) \\
\hline & $36-45$ & Age (Years) & Age (Years) \\
\hline & 46 and Above & 7 & 5.0 \\
\hline & Total & 139 & 100 \\
\hline \multirow[t]{6}{*}{ Level of Education } & MCE / SPM & MCE / SPM & MCE / SPM \\
\hline & Diploma & Diploma & Diploma \\
\hline & Bachelor's degree & Bachelor's degree & Bachelor's degree \\
\hline & Master & Master & Master \\
\hline & $\mathrm{PhD}$ & $\mathrm{PhD}$ & $\mathrm{PhD}$ \\
\hline & Total & 139 & 100 \\
\hline \multirow[t]{6}{*}{ Position } & Clerk & 34 & 24.5 \\
\hline & Salesman & 62 & 44.6 \\
\hline & Helper & 15 & 10.8 \\
\hline & Technical Staffs & 9 & 6.4 \\
\hline & Others & 19 & 13.7 \\
\hline & Total & 139 & 100 \\
\hline
\end{tabular}




\section{Reliability Analysis}

The reliability analysis was done to test both the consistency and stability of the data. As reported in Table 2, all the variables were deemed reliable as the Cronbach's Alpha values were recorded above 0.6 .

Table 2

Reliability Test Analysis

\begin{tabular}{lcc}
\hline Variables & Number of Items & $\alpha$ \\
\hline Staff training & 7 & .66 \\
Rewards and recognitions & 6 & .74 \\
Performance appraisal & 6 & .85 \\
Organizational performance & 6 & .83 \\
\hline
\end{tabular}

\section{Descriptive Statistics}

The descriptive statistics for this study are shown in Table 3 and 4 below. Overall, the mean scores for each variable was moderately high between 3.42 to 3.86 . The dependent variable, i.e. organizational performance recorded the highest mean score $(M=3.86, S D=.65)$ whereas the independent variable, i.e. performance appraisal $(M=3.85, S D=.71)$ recorded the highest mean score compared to staff training and rewards and recognitions.

Table 3

Summary of Descriptive Statistical Results $(n=139)$

\begin{tabular}{|c|c|c|c|c|c|}
\hline Variables & Min. & Max. & $M$ & $S D$ & Variance \\
\hline Staff training & 1.60 & 5.00 & 3.42 & .71 & .50 \\
\hline Rewards and recognitions & 1.17 & 5.00 & 3.76 & .66 & .43 \\
\hline Performance appraisal & 1.83 & 5.00 & 3.85 & .71 & .50 \\
\hline Organizational performance & 1.83 & 5.00 & 3.86 & .65 & .43 \\
\hline
\end{tabular}

Table 4 presents the mean scores for each item presented in the questionnaire. Based on the responses, it is interesting to note that 'staff training' recorded the lowest mean score of 3.42 as the respondents believed that their training needs were not identified, and the training schedule was not satisfactory. However, they believe that training provides a lot of benefits, among others, in improving skills, knowledge, attitude and new capability.

In terms of 'performance appraisal' $(M=3.85)$, the respondents believe that appraisal rating is important to help employees identify their own strengths and weaknesses and that it motivates their work motivation. As for 'rewards and recognitions' $(M=3.76)$, the respondents perceived that remunerations from employers are crucial to boost work performance and that giving rewards and recognitions are a form of compensation when change occurs in the management. 
Table 4

Mean Scores for Staff Training, Performance Appraisal and Rewards and Recognitions $(n=139)$

\begin{tabular}{|c|c|}
\hline Item & Mean \\
\hline Staff Training & 3.42 \\
\hline 1. Training needs of workers is identified. & 1.14 \\
\hline 2. Training Schedule & 2.54 \\
\hline 3. Staffs training affect organizational performance in change management process. & 4.02 \\
\hline 4. Training is relevant to respondent work & 4.15 \\
\hline 5. Managers, supervisors and HR influence on the selection of employee for training. & 3.89 \\
\hline 6. Training improves skill, knowledge, attitude and new capability. & 4.16 \\
\hline 7. Training helps me to enhance the use of tools and machines and operational safety & 4.06 \\
\hline Performance Appraisal & 3.85 \\
\hline 1. The performance appraisal rating is helpful to identify the strength and weakness of the employee. & 3.95 \\
\hline 2. Performance appraisal influences my motivation of work. & 3.99 \\
\hline 3. Performance appraisal affects working relationships with my colleagues at work. & 3.72 \\
\hline 4. The evaluation results impact my behaviour, attitudes and morale. & 3.82 \\
\hline 5. The organization derives benefits from the performance appraisal. & 3.89 \\
\hline 6. Evidence of performance is well documented and available for reference if needed. & 3.74 \\
\hline Rewards and Recognitions & 3.76 \\
\hline 1. Reward and recognition is a good compensation in change management process. & 4.08 \\
\hline 2. My salary level is frequently increased. & 2.82 \\
\hline 3. I have awareness of reward system in my organization. & 3.38 \\
\hline 4. When I get a bonus and remuneration my job performances increase. & 3.98 \\
\hline 5. When I am promoted by employer it really motivates me to work harder. & 4.12 \\
\hline 6. Commissions from employer helps to boost my performances. & 4.20 \\
\hline Organizational Performance & 3.86 \\
\hline 1. Management has achieved organization goals. & 3.48 \\
\hline 2. I feel the performance of this organization over the past three years has been excellent in meeting its goals. & 3.73 \\
\hline 3. I feel the organization can clearly measure the benefits it provides to employees or stakeholders. & 3.66 \\
\hline 4. Objectives set in the performance appraisal are aligned to the organizational objectives. & 3.80 \\
\hline 5. The firm has a reputation of having high performing employees. & 4.15 \\
\hline 6. The firm is perceived as a successful business. & 4.33 \\
\hline
\end{tabular}

When it comes to the dependent variable, i.e. 'organizational performance', the respondents were able to perceive the success of the company and that it has the reputation of having highperforming employees. These are among the top reasons associated with the company's performance.

\section{Pearson's Correlation Coefficients}

To examine the correlations between the dependent and independent variables, Pearson's Correlation Coefficient was analysed and presented in Table 5. The findings indicated that all the independent variables have a positive correlation with organizational performance. The results also indicated that all three independent variables of staffs training, rewards and recognition, and performance appraisal were all significant $(p<.05)$ towards the organizational performance. It can be seen from the result that the null hypothesis should be rejected thereby concluding that there is a relationship between all the independent variables and the dependent variable of organizational performance.

Table 5

Pearson's Correlation Coefficient for Independent Variables and Dependent Variable $(n=139)$

\begin{tabular}{lcc}
\hline Independent Variables & $r$ & $p$ \\
\hline Staff Training & .20 & $.01^{*}$ \\
Rewards and Recognition & .18 & $.03^{*}$ \\
Performance Appraisal & .17 & $.04^{*}$ \\
\hline
\end{tabular}

$* p<.05($ two - tailed test $)$ 


\section{Regression Analysis}

Table 6 and 7 present the ANOVA regression analysis and regression analysis model summary. The ANOVA table shows significant value of the $\mathrm{F}$ statistic $(\mathrm{F}=2.14)$ that is less than .05 , which means that the model is significant statistically $(p=.000)$.

Table 6

Regression Analysis ANOVA $(n=139)$

\begin{tabular}{lccccc}
\hline Model & $S S$ & $d f$ & $M$ & $F$ & $p$ \\
\hline Regression Residual Total & 0.23 & 3 & .07 & 2.14 & .000 \\
& 4.79 & 134 & .03 & & \\
& & 137 & & & \\
\hline
\end{tabular}

Multiple regression analysis was run to predict the variance of dependent variable by regression of the independent variable. $\mathrm{R}$-squared $\left(\mathrm{R}^{2}\right)$ is a statistical measure of how close the data are to the fitted regression line. It is also known as the coefficient of determination, or the coefficient of multiple determination for multiple regression. Coefficient of determination, i.e. $\mathrm{R}^{2}$ value of .45 indicates $45 \%$ variation in organizational performance is due to the proposed model. Another 55\% of organizational performance can be explained by other variable which is not included in this study.

Table 7

Regression Analysis Model Summary

\begin{tabular}{|c|c|c|c|c|}
\hline Model & $\mathrm{R}$ & $\mathrm{R}^{2}$ & Adjusted $\mathrm{R}^{2}$ & Std. Error of the Estimate \\
\hline 1 & .22 & .45 & .42 & .18 \\
\hline
\end{tabular}

\section{Hypothesis 1}

$\mathrm{H}_{0}$ : There is no relationship between staffs training and organizational performance.

$\mathrm{H}_{1}$ : There is a relationship between staffs training and organizational performance.

Regression coefficient beta value between staff training and organizational performance is .20 and significant at .01. The data of staff training is below than .05. Hence, it shows that in this study, staff training is the main factor of change management affecting towards organizational performance in Jakel Trading Company Segamat. This finding is also consistent with Butali and Njoroge (2017) who also found a significant relationship between staff training and organizational performance. Another study by Bakar (2011) similarly showed the significance value 0.000 which is less than 0.05 which also indicated a statistically significant correlation between training and development, job satisfaction and organization performance. Therefore, $\mathrm{H}_{1}$ was supported.

\section{Hypothesis 2}

$\mathrm{H}_{0}$ : There is no relationship between reward and recognition and organizational performance.

$\mathrm{H}_{1}$ : There is a relationship between reward and recognition and organizational performance.

Regression coefficient beta value between reward and recognition and organizational performance is .18. The regression is significant at .03. The null hypothesis is rejected and the alternative hypothesis is accepted. The data shows it is significant because it is less than .05. It can be concluded that there was a significant correlation between reward and recognition with organizational performance. This is supported by Onyango (2012), who found that rewards positively affect organizational performance as the study shows the significance of .007 , which is less than .05. Another study by Aktar (2012) also revealed that there is a correlation between employees' rewards and organizations performance. 


\section{Hypothesis 3}

$\mathrm{H}_{0}$ : There is no relationship between performance appraisal and organizational performance.

$\mathrm{H}_{1}$ : There is a relationship between performance appraisal and organizational performance.

Regression coefficient beta value relationship between performance appraisal and organizational performance is .17 at the significance of .04 . Therefore, the null hypothesis is rejected because it shows that the significance value is less than .05 and thus proving the correlation between performance appraisal and organizational performance. This can be supported by a previous study by Iqbal et al. (2014), who found that there is a significant relationship between performance appraisal and organizational performance with a significance value of .34. Mwema and Gachunga (2014) also found that performance appraisal positively affected organizational performance with the significance value of .004 . Both studies recorded a significance value of less than .05.

\section{Conclusion}

In summary, this study has tested the significant relationship between staff training, rewards and recognitions as well as performance appraisal with the organizational performance in Jakel Trading Company Segamat. Based on the results from the questionnaire with 139 respondents, it was found that all variables have a positive relationship with organizational performance. In particular, staff training was the most significantly correlated followed by rewards and recognitions and finally performance appraisal.

When it comes to staff training, the employees were able to perceive the benefits of the trainings provided by the company to improve their knowledge and skills. The training provided not only motivates them to work harder but also encourages them to improve their career advancement. However, the company was not able to identify the training needs of their employees and schedule the planned trainings well. To further improve the organizational performance of Jakel Trading Company, extensive training programmes should be conducted to ensure the employees are continuously relevant to the changing needs of jobs and business. By increasing training to employees, they are given the opportunity to improve performance as they play an important role to improve organizational performance.

Apart from that, the employees also believe that rewards and recognitions improve performance and motivate them to work harder, which in turn increases the organizational performance. In line with the results, the organization should utilize various forms of reward and recognition programmes to drive behaviour of the staffs that promotes high performance. Recognition is one of the ways of giving a certain status to the staffs in an organization. Recognition describes how work of the staffs is evaluated and appreciation can be given to them as a return that they received from the organization. Reward and recognition are the ways the organization gives the staffs or their employees for their hard work in the organization. It is an important factor that the organization needs to consider in motivating their staffs for better organizational performance.

Lastly, performance appraisal also impacts the employee and organizational performance when employee receives feedback about themselves for area of improvement and development. Performance appraisal as one of the factors affecting organizational performance should be considered important. Employee performance should be clearly disclosed for them to improve themselves for better performance. Performance appraisal appears to be indispensable part in any 
human resource management system. By understanding their' attitude and behaviour, it can help improve the organizational performance.

To date, no study was conducted in this company and in this particular retail branch. However, as the research context was limited to the textile sector of Jakel Trading Company only, future research should consider a larger sample side and can be extended to different sectors of different industries to get more significant results. This study also examined only three independent variables namely staff training, reward and recognition and performance appraisal. Therefore, future studies may consider other change management factors which can also be used as independent variable to get more generalized results of the organizational performance. As most of the previous research had shown many variables that contributed towards successful change management, exploration of other factors is important to diversify the study.

To conclude, although there are several limitations to the study, it is believed that findings from this study would provide several contributions in terms of both theoretically and practically. Especially since most research in this field are conducted in countries outside of Malaysia, it is hoped that this study would contribute to the performance of local organizations.

\section{References}

Abbas, M. Z. (2014). Effectiveness of performance appraisal on performance of employees IOSR Journal of Business and Management (IOSR-JBM), 16(6), 173-178.

Adeyi, A. O., Apansile, E. K., Okere, W., \& Okafor, L. I. (2018). Training and development and organisational performance: Standpoint from Private tertiary institutions in Nigeria. Journal of Economics, Management and Trade, 21(12), 1-10. https://doi.org/10.9734/jemt/2018/44895

Ahmad, I., \& Din, S. (2009). Evaluating training and development. Gomal Journal of Medical Sciences, 7(2), 165 -166.

Ahmed, I., Ramzan, M., Mohammad, S. K., \& Islam, T. (2011). Relationship between perceived fairness in performance appraisal and OCB: Mediating role of organizational commitment. International Journal of Academic Research, 3(5), 15-20.

Aktar, S. (2012). The Impact of rewards on employee performance in commercial banks of Bangladesh: An empirical study. IOSR Journal of Business and Management, 6(2), 9-15. https://doi.org/10.9790/487x-0620915

Al-Haddad, S., \& Kotnour, T. (2015). Integrating the organizational change literature: A model for successful change. Journal of Organizational Change Management, 28(2), 234-262. https://doi.org/10.1108/JOCM-11-2013-0215

Appelbaum, S. H., Cameron, A., Ensink, F., Hazarika, J., Attir, R., Ezzedine, R., \& Shekhar, V. (2017). Factors that impact the success of an organizational change: a case study analysis. Industrial and Commercial Training, 49(5), $213-230$. https://doi.org/10.1108/ICT-02-2017-0006

Asfaw, A. M., Argaw, M. D., \& Bayissa, L. (2015). The impact of training and development on employee performance and effectiveness: A case study of district five administration office, bole sub-city, Addis Ababa, Ethiopia. Journal of Human Resource and Sustainability Studies, 3(4), 188-202. https://doi.org/10.4236/jhrss.2015.34025Basil, T., \& Helen T. (2013). Performance on the right hand side: Organizational performance as an antecedent to management control. Qualitative Research in Accounting and Management, 3/4, 316-346. https://doi.org/10.1108/QRAM-10-2012-0043

Bejinariu, A. C., Jitarel, A., Sarca, I., \& Mocan, A. (2017). Organizational change management-concepts definitions and approaches inventory. Management Challenges in a Network Economy: Proceedings of the MakeLearn and TIIM International Conference, (May), 321-330. Retrieved from http://www.toknowpress.net/ISBN/978-961-6914-21-5/papers/ML17-061.pdf

Butali, P., \& Njoroge, D. (2017). Training and development and organizational performance: The moderating effect of organizational commitment. International Journal of Scientific Research and Management, 5(11), 7381-7390. https://doi.org/10.18535/ijsrm/v5i11.06

Chandrasekar, K. (2011), Workplace environment and its impact on organisational performance in public sector organisations, International Journal of Enterprise Computing and Business Systems, 1(1), 1-16.

Cho, J., \& Dansereau, F. (2010). Are transformational leaders fair. A multi-level study of transformational leadership, justice perceptions, and organizational citizenship behaviors. The Leadership Quarterly, 21, 409-421. 
Civelek, M., Ključnikov, A., Dobrovič, J., \& Hudáková, M. (2016). A model of measurement of the quality of business environment in SME segment. Journal Of International Studies, 9(2), 90-102.

Gavrea, C., Ilieş. L., \& Stegerean, R. (2011). Determinants of Organizational performance: The case of Romania. Management and Marketing Challenges for the Knowledge Society, 6(2), 285-300.

Decker, P., Durand, R., Mayfield, C. O., McCormack, C., Skinner, D., \& Perdue, G. (2012). Predicting implementation failure in organization change. Journal of Organizational Culture, Communication and Conflict, 16(2), 29-49.

Deming, W. E. (1982). Quality, productivity and competitive position, mit center for advanced engineering. Cambridge, MA

Deeprose, D. (1994). How to recognize and reward employees. Newyour: Amacom

Dobrovic, J., \& Timkova, V. (2017). Examination of factors affecting the implementation of organizational changes. Journal of Competitiveness, 9(4), 5-17. https://doi.org/10.7441/joc.2017.04.01

Engetou, E. (2017). The impact of training and development on organi-zational performance. Case study: National Financial Credit Bank Kumba. Centria University of Applied Sciences Business Management.

Fey, C. F., \& Bjorkman, I. (2001). The effect of human resource management practices on mncsubsidiary performance in Russia, Journal of International Business Studies, 32(1), 59-75.

Ghafoor, K., Furqad A. K., \& Aslam, K. M. (2011). Impact of training and development on organizational performance. Global Journal of Management and Business Research, 11(7).

Goel, D. (2008). Performance appraisal and compensation management: A modern approach. New Dehli: Prentice Hall of India.

Goulet, L. R., \& Singh, P. (2002). Career commitment: A reexamination and an extension. Journal of Vocational Behavior, 61(1), 73-91.

Halkos, G. (2012). Importance and influence of organizational changes on companies and their employees. University of Thessaly, Department of Economics. George, 69(36811). https://doi.org/10.1177/0019793916644755.

Ikinci, S. S. (2014). Organizational change: Importance of leadership style and training. Management and Organizational Studies, 1(2), 122-128. https://doi.org/10.5430/mos.v1n2p122

Iqbal, N., Ahmad, N., Haider, Z., Batool, Y., \& Ul-ain, Q. (2014). Impact of performance appraisal on employee's performance involving the moderating role of motivation. Oman Chapter of Arabian Journal of Business and Management Review, 3(1), 37-56. https://doi.org/10.12816/0002354

Hughes, M. (2011). Do 70 per cent of all organizational change initiatives really fail. Journal of Change Management, 11(4), 451464. https://doi.org/10.1080/14697017.2011.630506

Markos, S., \& Sridevi, M. S. (2010) Employee engagement: The key to improving performance. International Journal of Business and Management, 5, 89-96.

McLagan, P.A. (2009). The change-capable organization. Training and Development, 57(1), 51-57.

Merkova, M., Rajnoha, R., \& Dobrovič, J. (2016). Business performance and participation of foreign capital. Actual Problems of Economics, 180(6), 144-157.

Mwema, N. W., \& Gachunga, H. G. (2014). The influence of performance appraisal on employee productivity in organizations: A case study of selected WHO offices in East Africa. International Journal of Social Sciences and Entrepreneurship, 1(11), 324-337.

Nassazi, A., (2013). Effects of training on employees performance. University Of Applied Sciences, Uganda retreived from http://theseuskk.lib.helsinki.fi/bitstream/handle/10024/67401/THESIS.pdf?sequence=1

Onyango, T. O. (2012). The influence of training and development on employees performance at Mudete tea factory. International Journal of Scientific Research and Management, 6(3), 191-198.

Pakdel, A. (2016). An investigation of the difference in the impact of demographic variables on employees' resistance to organizational change in government organizations of Khorasan Razavi. Procedia - Social and Behavioral Sciences, 230(May), 439-446. https://doi.org/10.1016/j.sbspro.2016.09.055

Rein, C., Jan, V., \& Wilfred, U. (2016). Leading a successful change intervention in a modern organisation: Key elements to consider. African Journal of Business Management, 6(51), 12068-12075. https://doi.org/10.5897/ajbm12.1444

Rosenberg, S., \& Mosca, J. (2016). Breaking down the barriers to organizational change. International Journal of Management \& Information Systems (IJMIS), 15(3), 139. https://doi.org/10.19030/ijmis.v15i3.4650

Sanyal, S., \& Hisam, M. W. (2018). Impact of training and development on the performance of employees - A comparative study on select banks in sultanate of Oman. International Journal of Scientific Research and Management, 6(03), 191-198. https://doi.org/10.18535/ijsrm/v6i3.em02 
Sehgal, S (2012). Job satisfaction of bank employees in Shimla: "A comparative study of private and public sector bank (AXIS Bank \& UCO Bank).” Retrieved from http://www.indianresearchjournals.com/pdf/IJMFSMR/2012/July/10.pdf

Shafiq, S., \& Hamza, S. M. (2017). The effect of training and development on employee performance in private company, Malaysia. International Journal of Education,Learning Learning and Training, 2(2), 42-56. https://doi.org/10.20448/journal.500/2016.3.1/500.1.29.33

Siaguru, F. (2011). Performance appraisal systems: procedural and implementation issues in papua new guinea. Journal of Management Policy and Practice, 12(5),116-127. Retrieved from the Walden Library using ABI/INFORM Complete.

Tabassi, A., Ramli, M., \& Bakar, A., (2011). Training and development of workforces inconstruction industry. International Journal of a Cademic Research, https://www.academia.edu/1437515/training_and_development_of_workfo rces_in_construction_industry?auto=download

Wan, D., Kok, V., \& Hong, C. H. (2002). Strategic human resource management and organizational performance in Singapore, Compensation and benefits. Review Saranac, 39(4), 836-866.

Yang, Y. S., \& Kim, D. H. (2013). Nurses' professionalism and job satisfaction on the level of delegation of nursing activities in long-term care hospitals. Journal of Korean Gerontological Nursing, 15(2), 175-84.

Yasmeen. R, Farooq., U, \& Asgha, F. (2013). Impact of rewards on organizational performance: empirical evidence from Telecom sector of Pakistan. Journal of Basic and Applied Scientific Research, 3(5), 938-946

Zaleska, K. J., \& de Menezes L. M. (2007). Human resources development practices and their association with employee attitudes: Between traditional and new careers. Human Relations International Journal of Science and Research, 7(9), 685-690 